\title{
The Deterministic Elements of FDI to ASEAN Countries: The Relationship between FDI and Macroeconomic Variables
}

\author{
Yutaka Kurihara $^{1}$ \\ ${ }^{1}$ Department of Economics, Aichi University, Nagoya, Japan \\ Correspondence: Yutaka Kurihara, Department of Economics, Aichi University, 4-60-6 Hiraike, Nakamura, \\ Nagoya 4538777, Japan. Tel: 81-52-564-6111. E-mail: kurihara@vega.aichi-u.ac.jp
}

This study is supported by Japanese KAKEN (Ministry of Education, Culture Sports, Science \& Technology).

Received: March 14, 2012 Accepted: March 23, 2012 Online Published: May 24, 2012

doi:10.5539/jms.v2n2p11 URL: http://dx.doi.org/10.5539/jms.v2n2p11

\begin{abstract}
This article examines the deterministic elements of FDI (foreign direct investment) flows into ASEAN countries. It uses a panel data in ASEAN countries and US to analyze the relationship between FDI into ASEAN and macroeconomic variables. Domestic (ASEAN) economic growth, domestic prices in ASEAN and US prices promote FDI into ASEAN. On the other hand, the relationships between FDI volatility and domestic GDP, and the FDI volatility and US price, are not found. Rises in domestic prices increase FDI volatility.
\end{abstract}

Keywords: ASEAN, FDI, panel data

\section{Introduction}

The Asian economies have expanded rapidly from the 1980s under the process of globalization. One reason is FDI (foreign direct investment). It might have contributed to economic growth. Engel and Procher (2012) showed that firms with a broader investment strategy show higher productivity levels than firms with less encompassing foreign investment strategies. Much study has examined the reason why inflow into this area has occurred because of the recent high growthand high potentiality.

According the official website, ASEAN (the Association of Southeast Asian Nations) was established on 8 August 1967 in Thailand with the sign of the Declaration, namely Indonesia, Malaysia, Philippines, Singapore and Thailand. Brunei Darussalam then joined on 7 January 1984, Viet Nam on 28 July 1995, Lao PDR and Myanmar on 23 July 1997, and Cambodia on 30 April 1999.

The aims and purposes of ASEAN are; 1 . To accelerate the economic growth, social progress and cultural development in the region through joint endeavors in the spirit of equality and partnership in order to strengthen the foundation for a prosperous and peaceful community of Southeast Asian Nations; 2. To promote regional peace and stability through abiding respect for justice and the rule of law in the relationship among countries of the region and adherence to the principles of the United Nations Charter; 3. To promote active collaboration and mutual assistance on matters of common interest in the economic, social, cultural, technical, scientific and administrative fields; 4 . To provide assistance to each other in the form of training and research facilities in the educational, professional, technical and administrative spheres; 5 . To collaborate more effectively for the greater utilization of their agriculture and industries, the expansion of their trade, including the study of the problems of international commodity trade, the improvement of their transportation and communications facilities and the raising of the living standards of their peoples; 6. To promote Southeast Asian studies; and 7.To maintain close and beneficial cooperation with existing international and regional organizations with similar aims and purposes, and explore all avenues for even closer cooperation among themselves (Official website of the Association of Southeast Asian Nations). ASEAN has achieved very rapid industrialization and economic growth. Recently, the factors underlying ASEAN economic growth have started to be discussed.

This article examines the deterministic elements of FDI inflows into ASEAN countries empirically. It uses a panel data in ASEAN countries and US to analyze the relationship between FDI into ASEAN and some macroeconomic variables. By now, FDI's analysis has been related with economic growth. Recent examples are Argiro and Dimitrios (2011), Gauray and Aamir (2011), Moon et al. (2011), Polpat et al. (2011), Anowar and 
Kamal (2012) and Falah, et al. (2012). However, the number of articles which focus on FDI and ASEAN is few and most of these articles examine only the determinants of the "level" of FDI. Few of them examine the "volatility" of the FDI in spite of the importance.

The selection of deterministic elements for FDI has not any consensus. Some papers employ gravity model and use some explanation variables for empirical analysis. The typical variables employed often are GDP (output) and distance between the units (countries). This article focuses ASEAN nations, so distance between US and ASEAN country is not so important deterministic element. GDP is employed mostly often, moreover, some other important macroeconomic variables for FDI, namely, prices and interest rates are employed. They are often employed for examining FDI not only gravity model but also other models including theoretical ones.

Tesar and Werner (1995) and Albuquerque (2003) showed that the share of FDI in inflows is highin emerging countries. Alfaro et al. (2007) focused the importance of domestic factors, such as institutional quality and the soundness of macroeconomic policies. IMF (2007) showed that financial openness and institutional quality are linked with activeFDI inflows both in emerging and developedeconomies. Dipinder (2011) focused on Malaysia and emphasized on the importance of banking and capital market reforms for economic growth. Muhammad and Patrick (2011) focused on financial market integration and analyzed the correlation between savings and investment. Soyoung and Yong (2011) showed that capital inflows had contributed to asset price rises in emerging economies. Moreover, Imouda (2012) showed that there is the need to liberalize the foreign sector in Nigeria which all barriers that are inimical to bilateral trade.

This article focuses on not only the level of FDI but also the volatility of FDI. Bekaert and Harvey (1997), Lagoarde-Segot (2009) and Umutlu et al. (2010) concluded that financial liberalization reduces the volatility of stock market prices in emerging economies. Eichengreen (2001) indicated that vulnerabilities of emerging countries with weak domestic financial systems change capital account liberalization are related with the volatility of FDI. Broner and Rigobon (2005) showed that the higher volatility of FDI in emerging countries is due to these countries' propensity to make mismatches among markets. The distinct behavior of capital flow volatility can also be characterized by type of investment. Goldstein and Razin (2006) found that the gap between the volatility of FDI and financial portfolio flows is smaller in developed countries.

Other articles employ panel data models to analyze the impact of financial integration on FDI volatility. Engle, Gonzalo and Rangel (2008) and Broto et al. (2011) employed the method that generates volatilities with a low correlation than the other studies. Neumann et al. (2009) showed that financial integration tends to increase the volatility of FDI in emerging economies. Chee-Keong and Siew-Yong (2011) showed that financial sector development is a significant element for FDI. Managing volatile international flows is especially challenging for emerging countries, where FDI inflows are more volatile than in developed countries. As these studies, volatility of FDI should be noted and examined carefully along with the level of the FDI.

As the same with the case of the analysis of the level, two macroeconomic variables, namely prices and interest rates are used. One reason is that it would be appropriate in analysis to use the same variables with the case of level when analyzing FDI volatility. The other reason is that the situation of financial markets can be taken into account by including interest rates as explanation variables as the definition of FDI is sometimes ambiguous. Real transaction is sometimes related with financial transaction in FDI.

This article examines the deterministic elements of FDI inflow by fitting a panel data model from 2002 to 2010 . Section 2 introduces the data and methodology. Section 3 shows the empirical results and analyzes them. Section 4 concludes.

\section{Methodology}

The data employed here is yearly due to the lack of it. It is impossible to estimate equations of each country by quarterly or monthly data. Panel data, the same units of observation in a cross-sectional sample are surveyed times, is employed in this article.

For the volatility of FDI inflow, the standard deviation over a rolling window of annual data (three years) as Neumann et al. (2009) and IMF (2007). A panel data set to analyze which factors explain the observed volatility patterns. The estimation method is least squares. The sample period is from 2002 to 2011.

The estimated equation is

$$
\text { FDI(level/volatility })_{i t}=\alpha X_{i t-1}+\varepsilon_{i t} i=1, \ldots N, t=1, \ldots T
$$

where $\mathrm{X}_{\mathrm{it}}$ is a vector of independent variables and $\alpha$ is a vector of unknown coefficients. The estimation includes each country's fixed effects, 


$$
\varepsilon_{i t}=\varepsilon_{a i}+\varepsilon_{b i t}
$$

where $\varepsilon_{\mathrm{ai}}$ is a country fixed effect and $\varepsilon_{\mathrm{bit}}$ is an error term. The matrix contains the volatility determinants. Employing lagged explanatory variables to avoid problems of endogeneity is one choice, however, the data employed in this article is yearly (not quarterly or monthly) and the number of the samples is not large.

There is no consensus about the selection of explanatory variables that affect FDI. Broto et al. (2011) divided the explanatory variables into two, namely, domestic and world ones. A large set of explanatory factors can be adequately groupedin two categories: domestic macroeconomic variables and US macroeconomic variables in this article. The economic relationship between the ASEAN and US has been strong.

Ho and Ahmad (2011) showed that rate of economic growth and degree of openness significantly affect FDI flows in most ASEAN countries, however, inflation rate played a significant role in FDI flows only for Thailand. Muhammad and Muhamadd (2011) indicated that there was a positive relationship between market size, infrastructure, Inflation and FDI. Prema-Chandra and Swarnim (2011) listed dualistic investment policy and the narrow domestic human capital as determinant elements of FDI. Based on these previous studies, three US factors: the rate of growth of US GDP, US inflation (CPI), and the US interest rate (3-month T-bill rate) are used.Incorporating other developed countries as explanation variables would be necessary, however, such analysis would become too complex.

The domestic macroeconomic variables are growth of GDP, inflation (CPI) and interest rate (money market rate). Among them, interest rate is related with financial market's openness and investment. For the domestic interest rates, interest rates spreads (lending rates minus deposit rates) are employed. They mean not only the investment condition but also domestic financial market competitiveness.US interest rates employed here are not spreads.

Domestic GDP, prices, and interest rates in usual positively affect FDI inflows. All of these are push determinants to FDI. On the other hand, US GDP, prices, and interest rates usually negatively affect FDI flows into ASEAN.

This paper takes into both levels and volatility of FDI account. Much attention has not been paid to volatility of FDI. There is little study tackling this point. However, stable inflow into emerging economies is sometimes very important for economic growth in the middle- and long-term. However, the relationship with FDI inflow volatility is ambiguous not only theoretical but also empirical.

The stability of domestic economic growth and prices promote stable FDI to these countries in general if the economic expansion is surely positive. So the coefficient of FDI volatility is negative, however, if for example economic growth has not been attained sustainably or has been too rapidly or unstable, markets (firms) expect large fluctuation in GDP and prices. In this case, the coefficient is positive as Ramey and Ramey (1995) and Easterly et al. (2000). Lower interest rates spreads should reflect more competitive domestic financial systems. As Broto (2011) indicated, higher competition could imply lower volatility to the economy as a result of a deeper banking system, the coefficient is positive. However, higher volatility coming from more competition could lead to more FDI intermediated abroad. In this case, the coefficient is negative. Among them, interest ratesmay be related with financial market's openness and investment policy so it would be difficult to judge and expect it.

For US factors against FDI volatility, the coefficients are also ambiguous. A decrease in US GDP growth, US prices, and T-bill rate are likely to spark a flight abroad including ASEAN. In general, the coefficients of them against FDI volatility are negative if the ASEAN growth is stable. However, if US markets expand stably, there is some demand for FDI not only in US but also in emerging economics. Moreover, the expansion of ASEAN marketis too rapid or too large, there is a little demand to FDI in the emerging economies in spite of their growth. In this case, the growth rates increase volatility in their economy.The coefficients are positive. For the US interest rates, they depend on the domestic and US financial markets conditions.

Finally, unit root should be examined. The data used in this analysis is panel data. Levin-Liu-Chu panel data unit root test (LLC test) is performed. The test assumes that each individual unit in the panel have the same AR(1) coefficient, but allows for individual effects, time effects and a time trend. Lags of the dependent variable may be introduced to allow for serial correlation in their errors. t-star statistic is distributed standard normal under the null hypothesis of nonstationarity. All of the data are from International Financial Statistics by International Monetary Fund.

\section{Results and Analyses}

Table 1 and Table 2 report the estimates for the FDI. Table 1 shows the case of its level. LLC test is performed later. 
Table 1. Level of FDI to macroeconomic variables

\begin{tabular}{llll}
\hline Constant & $-424909.7^{* *}$ & $-111735.6^{* * *}$ & $-183996.9^{* * *}$ \\
GDP & $(-3.258)$ & $(-6.375)$ & $(-6.532)$ \\
& $-0.289^{* *}$ & -0.073191 & \\
Price & $(-2.142)$ & $(-1.510)$ & \\
& $1233.047^{* *}$ & $1882.143^{* * * *}$ & \\
Interest rate & $(2.727)$ & $(4.675)$ & \\
& $8121.474^{* * *}$ & $3586.428^{* * *}$ & \\
US' GDP & $(4.887)$ & $(3.154)$ & -6.603492 \\
& -20.21491 & & $(-0.722)$ \\
US' price & $(-1.613)$ & & $3082.956^{* * *}$ \\
& $7706.563^{* * *}$ & & $(3.279)$ \\
US' interest rate & $(3.978)$ & & $1532.397^{*}$ \\
& -2725.526 & & $(1.680)$ \\
Adj. ${ }^{2}$ & $(-1.626)$ & 0.969 & 0.951 \\
F-statistic & 0.991 & 84.631 & 53.105 \\
Durbin-Watson & 156.100 & 2.457 & 2.442 \\
\hline
\end{tabular}

Note: t-statistics are in parentheses. ${ }^{* *},{ }^{* *}$, and $*$ indicate significant at $1 \%, 5 \%$, and $10 \%$ respectively.

The results are very interesting. Against the expectation based on theoretical view, coefficient of domestic GDP is negative, however, prices are positive (expected). They are both significant. Foreign companies entered into ASEAN countries because of low wage and skilled labor. Moreover, they have expected to expand their sales in ASEAN countries. They would like to continue to expect relatively low wage in ASEAN, however, they may sometimes expand their sales to other countries, especially in Asia (not necessarily ASEAN). Broto et al. (2012) indicated that there is a structural breaking point around 2000 in emerging economies capital flow. For the interest rate, the result is expected as foreign companies do not expect financing necessary capital in ASEAN.

The sign of the coefficients of US GDP and interest rate are expected, however they are not significant at $10 \%$ level. The result of US price is against the expectation and significant. US firms may expect to manufacture products in ASEAN, import and sell them in US.

Table 2 uses rates for all dependent and independent variables. The null hypothesis of nonstationarityby LLC test was not rejected in many cases of the level, however, all of the data in the case of rate is stable at least at $10 \%$ level. So it would be better to use the rates as explanatory variables.

Table 2. Rate of FDI to macroeconomic variables rates

\begin{tabular}{llll}
\hline Constant & 1.195 & $-2.798^{* *}$ & 0.733 \\
& $(0.167)$ & $(-2.716)$ & $(1.303)$ \\
GDP & -16.670 & 6.103 & \\
& $(-0.532)$ & $(0.871)$ & \\
Price & 10.576 & $18.316^{* *}$ & \\
& $(0.533)$ & $(2.945)$ & \\
Interest rate & 0.080 & $0.287^{* * *}$ & -8.218 \\
& $(0.132)$ & $(3.592)$ & $(-0.950)$ \\
US' GDP & -35.322 & & 28.052 \\
& $(-0.795)$ & & $(1.541)$ \\
US' price & 33.814 & & 0.106 \\
& $(0.454)$ & & $(1.324)$ \\
US' interest rate & 0.157 & 0.591 & 0.250 \\
& $(0.869)$ & 4.379 & 1.780 \\
Adj. R & 0.485 & 1.635 & 2.430 \\
F-statistic & 2.098 & & \\
Durbin-Watson & 2.609 & & \\
\hline
\end{tabular}

Note: t-statistics are in parentheses. ${ }^{* *},{ }^{* *}$, and $*$ indicate significant at $1 \%, 5 \%$, and $10 \%$ respectively. 
The results are not so different from the results of Table 1. Some of results do not fit well with the hypotheses as explained in Table 1, however, the directions are not different from those in Table 1.

Table 3 reports the results in the case of FDI volatility.

Table 3. Volatility of FDI to macroeconomic variables rates

\begin{tabular}{llll}
\hline Constant & $-1.796^{* *}$ & $-2.042^{* * *}$ & 0.056 \\
& $(-2.259)$ & $(-3.299)$ & $(0.115)$ \\
GDP & -5.384 & -0.633 & \\
& $(-0.425)$ & $(-0.171)$ & \\
Price & $18.397^{* * *}$ & $15.466^{* *}$ & \\
& $(3.316)$ & $(2.903)$ & \\
Interest rate & $0.1688^{*}$ & $0.264^{* * *}$ & -14.869 \\
& $(1.660)$ & $(3.526)$ & $(-1.613)$ \\
US' GDP & -18.331 & & 1.719 \\
& $(-1.249)$ & & $(0.142)$ \\
US' price & 4.1491 & & 0.024 \\
& $(0.215)$ & & $(0.318)$ \\
US' interest rate & 0.090 & & -0.051 \\
& $(1.312)$ & 0.605 & 0.870 \\
Adj. R & 0.697 & 5.084 & 2.010 \\
F-statistic & 4.076 & 1.993 & \\
Durbin-Watson & 2.378 & & \\
\hline
\end{tabular}

Note: $t$-statistics are in parentheses. ${ }^{* * *},{ }^{* *}$, and $*$ indicate significant at $1 \%, 5 \%$, and $10 \%$ respectively.

The regressions indicate that US factors appear to have a limited role in determining FDI volatility. Recently, higher US interest rates seem to be associated with higher FDI volatility and US inflation also seem to be positively linked to FDI volatility, however, all of them are not significant. Not only US's economic condition but also other countries ones may have to be considered. These results show difficulties for policy makers since the effect of US drivers might limit the stabilizing potential ASEAN's domestic policies.

For domestic determinants, the GDP coefficient (minus) shows that lower FDI volatility are associated with domestic GDP growth. This finding is consistent with Aghion et al. (2004) and IMF (2007). However, it is not significant. The coefficient of inflation is opposite. It is significantly positive and is related with the volatility of FDI. FDI becomes unstable along with the rises in inflation, however, the reasons may be different in each country and each time. Judging the reasons of inflation is important to decide FDI into ASEAN countries. Interest rates spreadsagainst FDI volatility are positive and significant. It suggests that higher banking competition (spreads are small) could be an element of stabilization in FDI. Nevertheless, to make an accurate assessment they should take into account the peculiarities of FDI flow as compared with other capital flow.Financial and economic conditions also affect FDI stability. Moreover, it suggests that the development of domestic banking system does not necessarily achieve more stable FDI.

\section{Conclusions}

This article examined empirically the deterministic elements of FDI inflows into ASEAN countries using panel data. Domestic economic growth andpricesin ASEAN countries and US prices promote FDI. On the other hand, the relationship between FDI volatility and domestic GDP is not found, however, domestic prices affect positively FDI volatility in ASEAN. However, other variables do not affect the stability of FDI.

There are some rooms for further study. This article focused on inward FDI, however, it would be necessary to examine the opposite case - outward FDI (Yan et al, 2012). Also RTA (regional trade agreement) or the participation in WTO (World Trade Organization) should be taken into account (Kurihara, 2011). Mainly from the micro side, each country, each product, each industry, each market (for example, wage, natural resource, and infrastructure) should be divided into and also divided into somesample periods. Bacchetta and van Wincoop (1998), Aghion et al. (2004) and Martin and Rey (2006) examined the role of incomplete information. Further study is necessary. 


\section{References}

Aghion, P., Bacchetta, P., \& Banerjee, A. (2004). Financial development and instability of open economies. Journal of Monetary Economics, 51, 1077-1106. http://dx.doi.org/10.1016/j.jmoneco.2003.12.001

Albuquerque, R. (2003). The composition of international capital flows: risk sharing through foreign direct investment. Journal of International Economics, 61, 353-383.

Alfaro, L., Kalemli-Ozcan, S., \& Volosovych, V. (2008). Capital flows in a globalized world: the role of policies and institutions. In S. Edwards (ed.), Capital Controls and capital Flows in Emerging Economies: Policies, Practices and Consequences, The University of Chicago Press, Chicago.

Anowar, H., \& Kamal, H. M. (2012). Empirical relationship between foreign direct investment and economic output in South Asian countries: A study on Bangladesh, Pakistan and India. International Business Research, 5(1), 9-21.

Argiro, M., \& Dimitrios, K. (2011). FDI and Economic Growth: Causality for the EU and ASEAN. Journal of Economic Integration, 26(3), 554-577.

Baccetta, P., \& van Wincoop, E. (2008). Capital Flows to Emerging markets: Liberalization, Overshooting and Volatility. Working Paper No. 6530, NBER.

Bekaert, G., \& Harvey, C.R. (1997).Emerging equity market volatility. Journal of Financial Economics, 43, 307-327. http://dx.doi.org/10.1016/S0304-405X(96)00889-6

Broner, F., \& Rigobon, R. (2008). Why are capital flows so much more volatile in emerging than in developed countries? Working Paper No. 328, Banco Central de Chile.

Broto, C., Díaz-Cassou, J., \& Erce, A. (2011). Measuring and explaining the volatility of capital flows to emerging countries. Journal of Banking \& Finance, 35, 1941-1953. http://dx.doi.org/10.1016/j.jbankfin.2011.01.004

Dimitar, G., \& Mund, M. (2012). Foreign investment and bribery: A firm-level analysis of corruption in Viewtnam. Journal of Asian Economics, 23(2), 111-124.

Dipinder, R. (2011). Banking and capital market reform in Malaysia. ASEAN Economic Bulletin, $28(3), 388-413$.

Easterly, W., Islam, R., \& Stiglitz, J. (2008). Shaken and stirred: explaining growth volatility. In B. Pleskovic \& N. Stern (eds.), Annual world bankconference on development economics. World Bank, Washington D.C.

Eichengrenn, B. (2008). Capital account liberalization: What do cross-country studies tell us? The World Bank Economic Review, 15, 341-365. http://dx.doi.org/10.1093/wber/15.3.341

Engel, D., \& Procher, V. (2012). Export, FDI and firm productivity. Applied Economics, 44, $1931-1935$. http://dx.doi.org/10.1080/00036846.2011.556591

Engle, R., \& Rangel, J. (2008). The spline GARCH model for unconditional volatility and its global macroeconomic causes. Review of Financial Studies, 21, 1187-1222.

Fatah, F. A., Othman, N., \& Abdullah, S. (2012). Economic growth, political freedom and human development: China, Indonesia and Malaysia. International Journal of Business and Social Science, 3(1), 291-305.

Gauray, A., \& Aamir, K. M. (2011). Impact of FDI in GDP: A comparative study of China and India. Journal of Business and Management, 6(10), 71-79.

Goldstein, I., \& Razin, A. (2006). An informationbased trade-off between foreign direct investment and foreign portfolio investment. Journal of International Economics, 70, 271-295. http://dx.doi.org/10.1016/j.jinteco.2005.12.002

H. C. Moon, J. L. C. Cheng, M. Y. Kim \& J. U. Kim. (2011). FDI, Economic Decline and Recovery: Lessons from the Asian Financial Crisis. Multinational Business Review, 19(2), $120-312$. http://dx.doi.org/10.1108/15253831111149762

Ho, C., \& Ahman, R. (2011). Macroeconomic and country specific determinants of FDI. The Business Review, $18(1), 219-226$.

IMF. (2007). Global Stability Report, September 2007.

Kurihara, Y. (2011). The Impact of Regional Trade Agreements on International Trade. Modern Economy, 2(5), 846-849. http://dx.doi.org/10.4236/me.2011.25094

Lagoarde-Segot, T. (2009). Financial reforms and time-varying microstructures in emerging equity markets. 
Journal of Banking and Finance, 33, 1755-1769. http://dx.doi.org/10.1016/j.jbankfin.2009.01.007

Lhee-Keong, L., \& Siew-Yong, L. (2011). Foreign direct investment, financial development and economic growth: Panel data analysis. Journal of Applied Economics, 10(2), 57-73.

Martin, P., \& Rey, H. (2006). Globalization and emerging markets: with or without crash? The American Economic Review, 96, 1632-1651. http://dx.doi.org/10.1257/aer.96.5.1631

Muhammad, A., Muhammad, F., Muzaffar, A., \& Muhammad, S. (2011). Market size effect on foreign direct investment: A Case of Malaysia. Journal of Contemporary Research in Business, 3(7), 1002-1007.

Neumann, R. M., Penl, R., \& Tanku, A. (2009). Volatility of capital flows and financial liberalization: Do specific flows respond differently? International Review of Economics and Finance, 18, 488-501. http://dx.doi.org/10.1016/j.iref.2008.04.005

Polpat, K., Bangorn, T., \& Paitoon, W. (2011). Does FDI enhance economic growth?: New evidence from East Asia. ASEAN Economic Bulletin, 28(2), 183-202.

Prema-Chandra, A., \& Swarnim, W. (2011). Foreign direct investment in Southeast Asia: Is Malaysia falling behind, ASEAN Economic Bulletin, 28(2), 115-133.

Ramey, G., \& Ramey, V. (2011). Cross-country evidence on the link between volatility and growth. The American Economic Review, 85, 1138-1151.

Soyoung, K., \& Yong, D. (2011). The impact of capital inflows on asset prices in emerging Asian economies: Is too much money chasing too little good? Open Economies, 22(2), 293-315.

Tesar, L., \& Werner, I. (1995). US equity investment in emerging stock markets. The World Bank Economic Review, 9(1995), 109-129.

Umutlu, M., Akdeniz, L., \& Altay-Salih, A. (2010). The degree of financial liberalization and aggregated stock-return volatility in emerging markets. Journal of Banking and Finance, 34, 509-521. http://dx.doi.org/10.1016/j.jbankfin.2009.08.010

Yan, C., Hsu, W. C., \& Chengi, W. (2012). Effects of outward FDI on home-country export competitiveness. Journal of Chinese Economic and Foreign Trade Studies, 5(1), 56-73. 